\title{
Group guidance as an alternative method to building religious character
}

\author{
Sutarto $^{1}$, Dewi Purnama Sari ${ }^{2}$ \\ Institut Agama Islam Negeri Curup \\ sutarto@iaincurup.ac.id
}

Submitted : 2020-08-27, Revised : 2020-09-15, Accepted : 2020-11-24

\begin{abstract}
This article is aimed to determine the effectiveness of group guidance in improving understanding, attitudes, and practice of religious character values in the aspects of faith, worship, morals, and muamalah. The method used was an experiment with a pretest-posttest control group design. The population consisted of 137 people. The number of samples was 30 students with a general school or junior high school education background. Fifteen students were taken as the experimental group, and fifteen others were taken as the control group. Samples were taken by purposive sampling technique. Data were collected using a questionnaire and analyzed using SPSS 16.0 for windows. The results of the study showed that the average score of the experimental group was higher than the control group. The t-test results also showed that group guidance could significantly improve understanding, attitudes, and practice of religious character values. This means that group guidance can be used as an alternative method for building religious character.
\end{abstract}

Keywords: Alternative Methods; Building Religious Character; Group Guidance

\section{Introduction}

The character possessed by an individual is one of the indicators that can be used to determine the quality of social life. Damage of social character is a sign that the country is on the verge of collapse (Lickona, 2014). Therefore, building character is a very important thing to do, both for the present and the future (Tiwari, 2020), so that the country can avoid destruction. One of the ways to develop character is through education (Lickona, 2014).

Education is not only aimed to merely build intellectual intelligence but also to develop individuals so that they have good character (Martin Luther King in Hafid, 2018; Maryani \& Pramesti, 2016; M. A. H. Putra, 2019). Therefore, this character can help individuals to develop emotions, as well as a spiritual personality that has positive traits that can lead to positive thoughts, feelings, and behavior. (Hidayat et al., 2018; Park et al., 2004), prevent their life from worries (Jafaripoor et al., 2019; Sawitri, 2018), avoid dependency of others (Singh \& Tyagi, 2020), and become happy (Mayasari, 2014; Yasipin et al., 2020).

Building character becomes the noble ideals of the Indonesian people that must be realized in the implementation of national education. These noble ideals are explained in the purpose of national education, which is to develop the potential of students to become human beings who believe in God Almighty, have good character, are healthy, knowledgeable, capable, creative, independent, democratic, and responsible (Act Number 20 of 2003, 2016). To realize this goal, five main character pillars must be developed in students, namely religious character, nationalism, independence, cooperation, and integration (Najmina, 2018). Religious character is the main and first character that must be developed in each self. If the religious character develops maximally, then humans will get a good life, both in the world and in the hereafter (Prayitno \& Amti, 2004). Undeveloped of a religious character in a person, not only affects the development of individual aspects but also disrupts the development of social and literary aspects (Prayitno \& Amti, 2004).

Character means personality, quality, or trait that shows the totality of a person (Arthur, 2010). The character has the same meaning as morality, which is the nature of the mind that affects the thoughts, actions, and behavior of a person in everyday life, which differs from one person to another (Indonesia, 2017). Park and Peterson (in Shoshani, 2019)define character as a positive quality or personality trait possessed by a person and is reflected in 
thoughts, feelings, and behavior. Character is a combination of internal qualities and behavior that distinguishes someone from others (Suyanto, 2016). Religious means carrying out religious teachings that are believed comprehensively (Mutohar, 2016; Nurlaeli et al., 2020). Glock\& Stark (in Jafaripoor et al., 2019) explain that religious means the highest values contained in the teachings of a religion that is believed, concerning aspects of belief, rituality, appreciation of the rituality, and the consequences of these beliefs.

In the Islamic perspective, religious is interpreted as the highest value found in the teachings of Islam, believed to be true, understood and manifested in the attitudes and behavior of daily life both in the aspects of faith, worship, morals, and muamalah (Ismail, 2016; Mutohar, 2016). Aspects of faith include faith in Allah, faith in angels, faith in books, faith in prophets and apostles, faith in the Day of Judgment, and faith in qodo and qadar (Yusoff, 2019). Aspects of worship include taharah, prayer, zakat, fasting, and pilgrimage (Sudarsono, 2018). Aspects of morals include morals towards Allah, morals for the Apostles, morals for parents, morals for teachers, and morals towards oneself (Nst, 2017). The muamalah aspect includes interactions among Muslims and interactions with non-Muslims (Noorhidayati, 2017). Religious character is the inner attitude of a person which influences the mind, attitude, and behavior that comes from the values of the religious teachings that are believed. A character so conceived has three interrelated parts: moral knowing, moral feeling, and moral behavior. Good character consists of knowing the good, desiring the good, doing the good-habits of the mind, habits of the heart, and habits of action (Lickona, 2014).

Religious characters are not innate but can be developed after birth (Santrock, 2017). Developing religious character can be done by increasing knowledge and understanding of Islamic teachings, improving the attitude of togetherness, and increasing the practice of religious teachings to become a better person (Prayitno \& Amti, 2004), both in aspects of faith, worship, morals, and muamalah (Yakub \& Abdurrahman, 2019). There are many ways to develop a religious character. One of them is through group guidance.

Group guidance is a type of service in guidance and counseling that is carried out by utilizing group dynamics (Sukma, 2018). In group guidance, it is discussed certain topics (Fron, 1969). Topics covered include challenging religious characters, both aspects of faith, worship, morals, and muamalah. A discussion of the topic is led by a group leader. Group members are invited together to express their opinions on the topics discussed (Syam \& Yusuf, 2019). The ultimate goal of group guidance is so that group members can increase their knowledge and understanding of the topics discussed (Aryani \& Bakhtiar, 2017), as a basic reference for making decisions in attitude and behavior.

Some previous research has already discussed religious character and group guidance. Research conducted by Khotimah (2016) discusses the management model of religious character education through religious and religious activities which include planning, implementation, and evaluation models. Development of religious character through religious extracurricular activities (Hambali \& Yulianti, 2018). Value education strategy in building the religious character (Cahyono, 2016). Building religious characters through full-day schools (Raharjo et al., 2018). Group guidance is very effective in improving communication skills (Fitria, 2013). Group guidance is very effective in improving the rational thoughts of bullying victims (Habsy, 2018). Group guidance is also very effective in improving student disciplinary behavior (S. Putra, 2019). However, there has not been specifically discussed building religious character in the aspects of understanding, attitudes, and practice of religious character values through group guidance. This study aims to determine the effectiveness of group guidance services in building the religious character of students, both aspects of understanding, attitudes, and practice of religious character values The results of this study are expected to make group guidance a method in building religious character, especially for students and humans in general. 


\section{Methods}

This is an experimental study, a study to find out changes in a condition if the condition is given treatment, then generalization is drawn for a wider population (Sugiono, 2018). The design used was a pretest-posttest control group design. In this design, the experimental group and the control group were given pre-test and post-test.In the experimental group, they were treated in the form of group guidance services 10 times with the first material, faith which includes faith in Allah, faith in angels, faith in books, faith in prophets and apostles, faith in the Day of Judgment, and faith in qoda and qadar. Second, worship, which includes taharah, prayer, fasting, zakat, and pilgrimage. Third, morals, which include morals towards Allah, morals for the Apostles, morals for parents, morals for teachers, and morals towards oneself. Fourth, muamalah, which includes interactions among Muslims and interactions with non-Muslims. Meanwhile, the control group before the post-test was given the same material but used classical information services. The results of the pre-test and post-test of the two groups were then compared to determine changes in the conditions or behavior of the experimental group and the control group (Sugiono, 2018).

The population of this research is the students of the Social Sciences department (IPS) of Madrasah Aliyah Negeri (MAN) Curup that consists of 137 people. The samples of this study were 30 students with general education or junior high school backgrounds. The sampling technique used was purposive sampling. The samples were divided into two groups, a control group of 15 people and an experimental group of 15 people.

The data were collected by using a questionnaire. This questionnaire is used to measure the level of knowledge, attitudes, and practice of students' religious character in the aspects of creed, worship, morals, and muamalah. A questionnaire to measure the level of understanding used an objective test with five alternative answers (a, b, c, d, and e) with 50 item items. Correct answers are given a score of 2 , with a maximum score of $2 \times 5=100$. To measure attitudes toward religious character values, a questionnaire was used consisting of many statements of attitudes toward religious character values in the aspects of faith, worship, morals, and muamalah. It consisted of 20 items of statements with alternative answers Very Agree (VG), Strongly Agree (SG), Agree (A), Not Agree (NRA) and Disagree (D). The highest score of $20 \times 5=100$ and the lowest score of $20 \times 1=20$. To measure the level of behavior or practice of religious character values, a questionnaire was used which contained statements about the practice of practising religious character values, including aspects of faith, worship, morals, and muamalah. This questionnaire consists of 20 items with five alternative answers: Always (A), Often (O), Sometimes (S), Rarely (R), and Never (N). The highest score is $20 \times 5=100$ and the lowest score is $20 \times 1=20$. The data obtained were then analyzed using SPSS 16.0 for windows.

\section{Results and Discussion}

The results show that group guidance can significantly enhance students' understanding, attitudes, and practice of religious character values. This can be seen from the results of data analysis as follows:

\section{Students' understanding of religious character values}

The results of data processing about students' understanding of religious character values for the control group and the experimental group both pretest and posttest can be seen in the table below: 
Table 1. Mean, Deviation Standard and 2-tailed of Knowledge

\begin{tabular}{llcc}
\hline \multicolumn{1}{c}{ Measurement } & & Experiment $(\mathbf{N}=15)$ & Control $(\mathbf{N}=15)$ \\
\hline Pretest & M & 59.2 & 60.5 \\
& SD & 8.05 & 9.3 \\
Posttest & M & 71.0 & 62.6 \\
& SD & 5.28 & 7.6 \\
\hline 2-tailed & & $0.00<0.05$ & $0.59>0.05$ \\
\hline
\end{tabular}

Table 1. shows that group guidance can improve student understanding of the values of a religious character. It can be seen that the average score of the experimental group is higher than the average score of the control group. The mean score of the experimental group's pretest was 59.2, the post-test was 71.0, with an increase of 11.8. While the mean score of the control group's pre-test was 60.5, and the post-test was 62.6, with an increase of 2.1.

\section{Attitudes of students towards religious character values}

The results of data processing about students' attitudes towards religious character values for the control group and the experimental group both pretest and posttest can be seen in the table below:

Table 2.Mean, Deviation Standard and 2-tailed of Attitude

\begin{tabular}{lccc}
\hline \multicolumn{1}{c}{ Measurement } & & Experiment $(\mathbf{N}=15)$ & Control $(\mathbf{N}=\mathbf{1 5})$ \\
\hline Pretest & M & 55.5 & 59.0 \\
& SD & 14.5 & 15.05 \\
Posttest & M & 74.4 & 59.86 \\
& SD & 8.7 & 14.6 \\
\hline 2-tailed & & $0.00<0.05$ & $0.037>0.05$ \\
\hline
\end{tabular}

Group guidance can also improve student attitudes toward religious character values. The increase can be seen in table 2, in which the average score in the experimental group increases higher than the control group. In the experimental group, an average score increased by 18.5 or from 55.5 to 74.4 , meanwhile, in the control group, there was only an increase of 0.86 in the average score of 59.0 to 59.86 .

\section{Students' practice of religious character values}

The results of data processing about students' practice of religious character values for the control group and the experimental group both pretest and posttest can be seen in the table below:

Table 3.Mean, Deviation Standard and 2-tailed of Behaviour

\begin{tabular}{llcc}
\hline \multicolumn{1}{c}{ Measurement } & & Experiment $(\mathbf{N}=\mathbf{1 5})$ & Control $(\mathbf{N}=\mathbf{1 5})$ \\
\hline Pretest & M & 55.5 & 56.9 \\
& SD & 11 & 10.7 \\
Posttest & M & 66.93 & 57.6 \\
& SD & 9 & 11.1 \\
\hline 2-tailed & & $0.00<0.05$ & $0.33>0.05$ \\
\hline
\end{tabular}

On the other hand, group guidance can also improve students' behavior/ practice of religious character values. From the results of data analysis, as shown in table 3 , it shows that in the experimental group, there was an increase in the average of 11.43 or from 55.5 to 66.93. While in the control group there was only an increase of 0.7 or 56.9 to 57.6. 
T-test results in the control group at the 0.05 significance level obtained 2-tailed values for aspects of knowledge, attitudes, and behavior, the value is smaller than 0.05 or $0.00<$ 0.05 . While in the control group, value 2 for aspects of knowledge, attitudes, and behavior, the value is greater than 0.05 or $>0.05$. This shows that group guidance services can improve students' understanding, attitudes, and behavior/practice of religious character values. This means that group guidance services can be used as a medium for developing religious character, both for students and humans in general.

Based on the table above, it can be seen that group guidance can be convincingly used as a forum for shaping religious character. The formation of religious characters can be seen with an increase of understanding, positive attitudes, and the practice of religious character values in daily life. This improvement in understanding occurs because joining group guidance enables group members to obtain a variety of knowledge and information related to religious character values in aspects of faith, worship, morals, and muamalah. This is in line with the main function of group guidance services, which is to provide understanding to group members about the topics discussed (Fitria, 2013; Leksana, 2011; Putri, 2013). In the context of group guidance, increasing understanding of the topic discussed is very important to do, because this will facilitate group members in planning and preparing for their future(Pranoto, 2016). Also, by increasing the understanding of group members, group members are expected to be able to understand themselves and their life goals (Pratama et al., 2019; Rahman \& Kasman, 2019; Syam \& Yusuf, 2019). This was also was stated by one of the Social Sciences Department students who attended the group's guidance. The student said after attending the group's guidance, he gained much information, knowledge, and understanding related to religious character values, both aspects of faith, worship, morals, and muamalah (Novianto, 2018).

Group guidance not only can increase understanding of religious values but also can improve student attitudes toward religious character values. This can be seen from the increase in the average score of the post-test of the experimental group that increased higher than the average score of the post-test in the control group and supported by the results of the t-test which showed that group guidance could significantly improve attitudes toward religious character value. Attitudes are not innate, but formed after the individual is born (Santrock, John W, 2012; Sutarto, 2018). Many any factors that can affect attitudes, including knowledge and understanding, values, education, life goals, emotions, environment, and so on (Albarracin \& Shavitt, 2018; Finseraas et al., 2018; Kim et al., 2014; Nurasiah et al., 2019). One of the positive attitudes of group members towards religious character values is the increasing of group members' understanding of the religious character values which is obtained through group guidance.

In terms of the process of implementing group guidance, group members were given the same opportunity to express their responses and opinions related to their attitudes and habits towards the values of a religious character. It was these responses, suggestions, and input from fellow group members that then raised awareness and determination for group members to improve the attitudes and habits that had so far been carried out about religious character values. Nursaiti, (2018) explained, before following the group's guidance, she had a habit of wearing the hijab and covering aurat only when in school, but after following the group's guidance, she realized wearing the hijab and covering aurat was an obligation for every Muslim. Group guidance can not only increase an individual's positive attitude toward religious character values, but also can increase an individual's positive attitude in other aspects, such as increasing the attitude of forgiveness (Salau et al., 2017), improving discipline (S. Putra, 2019), enhancing mutual respect (Utama, 2017), bettering manners (Apriatama, 2018), enhancing honesty (Fadilah, 2019), improving attitudes of individual and social piety (Falah, 2016), social attitude (Yetti, 2017), and so on. 
Increasing religious character not only happen in the aspect of understanding (cognitive) and positive attitude (affective), but also in the aspect of practising (conative) values. This increase can be seen by the increase in the post-test average score in the experimental group that is higher than the average score of the post-test of the control group. The results of the t-test also showed that significant group guidance could be used as a medium for building religious character. Increasing the practice (conative) of religious values in the experimental group is very possible to occur because, during the group's guidance, there was a sharing of experiences among group members. Each group member was asked to respond and provide input related to the practice of religious values among members of the group, whether it was following the provisions of religious teachings or not. Finally, awareness emerged to make improvements related to the practice of religious characters that had been carried out. On the other hand, an increase in the practice of religious values was due to an increase in the understanding and attitudes of group members towards the values of religious characters. Changes in one's attitude towards something happened because of a change in understanding (Jauhari \& Mulyadi, 2017; Yunus \& Ismail, 2017). Changes in attitude will also affect one's behavior (Akhrani, 2019). This is in line with the function of the attitude itself, that attitude serves to predict and direct individual behavior (Shahruddin et al., 2018).

\section{Conclusions and Suggestions}

Based on the results of the study, it can be concluded that building religious character can be done through group guidance. This is evidenced by the increase in the average score of religious characters in the experimental group that is greater than the control group, in all aspects of understanding, attitudes, and behavior. Based on the results of the t-test, it can be said that the guidance group can significantly improve religious character, both from the aspects of knowledge, attitudes, and behavior. The results of this study indicate that group guidance can not only be used to develop the potential of students but can also be used as an alternative method to build students' religious character.

\section{References}

Akhrani, L. A. (2019). Dapatkah religiusitas menyelamatkan anggota partai politik dari jeratan korupsi? kajian religiusitas terhadap sikap korupsi anggota partai politik. Interaktif: Jurnal Ilmu-Ilmu Sosial, 11(1), 69-92. https://interaktif.ub.ac.id/index.php/interaktif/article/view/198

Albarracin, D., \& Shavitt, S. (2018). Attitudes and attitude change. Annual review of psychology, 69, 299-327. https://www.annualreviews.org/doi/abs/10.1146/annurevpsych-122216-011911

Apriatama, D. (2018). Bimbingan kelompok berbasis nilai budaya belom bahadat untuk meningkatkan sikap sopan santun peserta didik di Madrasah Aliyah Negeri Kota Palangka Raya. Jurnal Bimbingan dan Konseling Ar-Rahman, 4(2), 61-72. http://dx.doi.org/10.31602/jbkr.v4i2.1515

Arthur, S. (2010). Reber \& Emily S, Reber. Kamus psikologi. Yogyakarta: Pustaka Pelajar.

Aryani, F., \& Bakhtiar, M. I. (2017). The Development of group guidance service model to increase the competence of counselor candidate. GUIDENA: Jurnal Ilmu Pendidikan, Psikologi, Bimbingan dan Konseling, 7(1), 121-129. http://dx.doi.org/10.24127/gdn.v7i1.600 
Cahyono, H. (2016). Pendidikan karakter: strategi pendidikan nilai dalam membentuk karakter religius. Ri'ayah: Jurnal Sosial dan Keagamaan, 1(02), 230-240.

Fadilah, S. N. (2019). Layanan bimbingan kelompok dalam membentuk sikap jujur melalui pembiasaan. Islamic Counseling: Jurnal Bimbingan Konseling Islam, 3(2), 167-178. http://dx.doi.org/10.29240/jbk.v3i2.1057

Falah, R. Z. (2016). Membentuk kesalehan individual dan sosial melalui konseling Multikultural. Konseling Religi: Jurnal Bimbingan Konseling Islam, 7(1), 163-188. http://eprints.stainkudus.ac.id/id/eprint/1310

Finseraas, H., Skorge, Ø. S., \& Strøm, M. (2018). Does education affect immigration attitudes? Evidence from an education reform. Electoral Studies, 55, 131-135. https://doi.org/10.1016/j.electstud.2018.06.009

Fitria, N. (2013). Model bimbingan kelompok berbasis falsafah hidup masyarakat Lampung untuk mengurangi prasangka sosial. Jurnal Bimbingan Konseling, 2(2). https://doi.org/10.15294/JUBK.V2I2.2718

Fron, J. A. (1969). The use of group guidance and group counseling at the elementary school level. https://scholar.google.com/

Habsy, B. A. (2018). Model bimbingan kelompok PPPM untuk mengembangkan pikiran rasional korban bullying siswa SMK etnis Jawa. JP (Jurnal Pendidikan): Teori dan Praktik, 2(2), 91-99.

Hafid, U. din. (2018). Konsep pendidikan karakter perspektif islam. Ta'dib: Jurnal Pendidikan Islam, 7(1), 454-460. https://doi.org/10.29313/tjpi.v7i1.3428

Hambali, M., \& Yulianti, E. (2018). Ekstrakurikuler keagamaan terhadap pembentukan karakter religius peserta didik di kota majapahit. PEDAGOGIK: Jurnal Pendidikan, 5(2), 193-208.

Hidayat, W., Ahmad, J. B., \& Hamzah, M. I. B. (2018). Nilai keutamaan pengetahuan dan kebijaksanaan dalam konteks pendidikan karakter bangsa. Jurnal Penelitian dan Evaluasi Pendidikan, 22(1), 82-91. https://doi.org/10.21831/pep.v22i1.18103

Indonesia, K. B. B. (2017). Kamus besar bahasa Indonesia (KBBI). Di akses pada Maret, 14, 2017. https://scholar.google.com/

Ismail, I. (2016). Character education based on religious values: An islamic perspective. Ta'dib: Journal of Islamic Education (Jurnal Pendidikan Islam), 21(1), 41-58. http://jurnal.radenfatah.ac.id/index.php/tadib/article/view/744

Jafaripoor, H., Ghomi, M., Mahmoodi, A., Tavan, B., \& Moslemi, A. (2019). Relationship of religiosity with mental health and life satisfaction in students of Arak University of Medical Sciences, Arak, Iran. Health, Spirituality and Medical Ethics, 6(3), 35-43. http://dx.doi.org/10.29252/jhsme.6.3.35

Jauhari, T., \& Mulyadi, M. (2017). Sikap dan perilaku beragama mahasiswa UIN Raden Intan Lampung. Bina'Al-Ummah, 12(2), 92-105. https://doi.org/10.24042/bu.v12i2.4763

Khotimah, K. (2016). Model manajemen pendidikan karakter religius di SDIT Qurrota A'yun Ponorogo. Muslim Heritage, 1(2), 371-388. 
Kim, J., Lee, J., Park, J., Choi, D. H., Kim, E., Kim, J., You, M., Lim, M., Lee, H., \& Ju, S. (2014). Comparative study on the attitudes of female seniors and female university students toward seniors. Technology and Health Care, 22(3), 489-495. https://doi.org/10.3233/THC-140808

Leksana, D. M. (2011). Keefektifan penerapan bimbingan kelompok dengan topik tugas untuk meningkatkan pemahaman pemilihan program penjurusan siswa. Jurnal Penelitian Psikologi Pendidikan dan Bimbingan (JP3B), $1(1)$. http://journal.upgris.ac.id/index.php/JP3B/article/view/275

Lickona, T. (2014). Pendidikan karakter panduan lengkap mendidik siswa menjadi baik dan pintar. Nusa Media.

Maryani, I., \& Pramesti, N. E. (2016). The role of Javanese culture in character building at elementary school. 2nd ICET Theme: "Improving The Quality of Education and Training Through Strengthening Networking,” 406. https://scholar.google.com/

Mayasari, R. (2014). Religiusitas islam dan kebahagiaan (sebuah telaah dengan perspektif psikologi). Al-Munzir, 7(2), 81-100. http://dx.doi.org/10.31332/am.v7i2.281

Mutohar, P. M. (2016). Pengembangan budaya religius (religious culture) di madrasah: strategi membentuk karakter bangsa peserta didik. Didaktika Religia, 1(1). https://doi.org/DOI : 10.30762/didaktika.v1.i1.p\%p.2013

Najmina, N. (2018). Pendidikan multikultural dalam membentuk karakter bangsa Indonesia. JUPIIS: Jurnal Pendidikan Ilmu-Ilmu Sosial, 10(1), 52-56. https://doi.org/10.24114/jupiis.v10i1.8389

Noorhidayati, S. (2017). Paradigma antroposentris dalam memahami hadis-hadis muamalah. Jurnal Theologia, 28(1), 103-122.

Nst, K. (2017). Konsep keutamaan akhlak versi al-Ghazali. Hijri, 6(1).

Nurasiah, N., Azis, A., \& Munira, W. (2019). The correlation between: awareness of history, religious values and multiethnic understanding with tolerance attitude. Paramita: Historical Studies Journal, 29(1), 10-17. https://doi.org/10.15294/paramita.v29i1.14861

Nurlaeli, N., Astuti, M., \& Handayani, T. (2020). Implementation of religious character education in an understanding of noncorruption education in elementary school/ implementasi pendidikan karakter religius dalam upaya pemahaman pendidikan anti korupsi di MI. Al-Mudarris: Journal of Education, 3(1), 66-80-80. https://doi.org/10.32478/al-mudarris.v3i1.390

Park, N., Peterson, C., \& Seligman, M. E. (2004). Strengths of character and well-being. Journal of social and Clinical Psychology, 23(5), 603-619. https://doi.org/10.1521/jscp.23.5.603.50748

Pranoto, H. (2016). Group guidance services with self regulation techniques for students. GUIDENA: Jurnal Ilmu Pendidikan, Psikologi, Bimbingan dan Konseling, 6(2), 180189. http://dx.doi.org/10.24127/gdn.v6i2.506

Pratama, Y. S., Wibowo, M. E., \& Awalya, A. (2019). Group counseling with psychodrama and sociodrama techniques to improve emotional intelligence. Jurnal Bimbingan Konseling, 8(1), 79-85. https://doi.org/10.15294/jubk.v8i1.27893

Prayitno, E. A., \& Amti, E. (2004). Dasar-dasar bimbingan dan konseling. Jakarta: Rineka Cipta. 
Putra, M. A. H. (2019). Building character education through the civilization nations children. The Kalimantan Social Studies Journal, 1(1), 12-17. https://doi.org/10.20527/kss.v1i1.1252

Putra, S. (2019). Efektifitas layanan bimbingan kelompok untuk meningkatkan sikap kedisiplinan siswa. Jurnal Penelitian Pendidikan Sosial Humaniora, 4(1), 493-500. https://doi.org/10.32696/jp2sh.v4i1.273

Putri, G. G. R. (2013). Penerapan bimbingan kelompok teknik home room untuk meningkatkan pemahaman siswa tentang bahaya seks bebas. Jurnal BK UNESA, 1(1). https://scholar.google.com/

Raharjo, T., Rohana, H., Istyarini, I., \& Nurussaadah, N. (2018). Pengaruh full day school terhadap pembentukan karakter religius siswa. Indonesian Journal of Curriculum and Educational Technology Studies, 6(1), 22-32.

Rahman, I. K., \& Kasman, R. (2019). Best practice Islamization of science on GestaltProfetik (G-Pro) guidance and counseling model. Ibn Khaldun Journal of Social Science, 1(1), 46-51. http://dx.doi.org/10.32832/ikjss.v1i1.2381

Salau, T. L., Wibowo, M. E., \& Loekmono, J. L. (2017). Pengembangan model bimbingan kelompok teknik bibliocounseling untuk meningkatkan sikap forgiveness siswa SMA Swasta Kota Atambua. Jurnal Bimbingan Konseling, 6(2), 196-205. https://doi.org/10.15294/JUBK.V6I2.21798

Santrock, J. W. (2017). Educational psychology. McGraw-Hill Education.

Santrock, John W. (2012). Perkembangan masa hidup jilid I. Erlangga.

Sawitri, E. (2018). Hubungan spiritualitas dengan kecemasan pada lansia. MOTORIK Jurnal Ilmu Kesehatan, 13(2), 64-72. https://scholar.google.com/

Shahruddin, N. J., Mansor, M., Madon, Z., \& Hamsan, H. H. (2018). Hubungan pengaruh rekan sebaya, estim diri dan lokus kawalan dengan sikap terhadap tingkah laku Seksual (relationship between peer influences, self esteem and locus of control with attitude towards sexual behavior). Akademika, 88(2). https://doi.org/10.17576/akad-2018-880206

Shoshani, A. (2019). Young children's character strengths and emotional well-being: Development of the Character Strengths Inventory for Early Childhood (CSI-EC). The Journal of Positive Psychology, 14(1), 86-102. https://doi.org/10.1080/17439760.2018.1424925

Singh, L. K., \& Tyagi, M. (2020). Relevance of Vivekananda's views on the process of character building. Studies in Indian Place Names, 40(60), 5986-5997. https://archives.tpnsindia.org/index.php/sipn/article/view/6615/6364

Sudarsono, S. (2018). Pendidikan ibadah perspektif Al-Quran dan Hadits. CENDEKIA: Jurnal Studi Keislaman, 4(1).

Sugiono. (2018). Metode penelitian pendidikan: pendekatan kuantitatif, kualitatig dan $R \&$ D. Alfabeta.

Sukma, D. (2018). Concept and application group guidance and group counseling base on Prayitno's paradigms. Konselor, 7(2), 49-54. https://doi.org/10.24036/02018728754-000 
Sutarto, S. (2018). Pengembangan sikap keberagamaan peserta didik. Islamic Counseling: Jurnal Bimbingan Konseling Islam, 2(1), 21-42. http://dx.doi.org/10.29240/jbk.v2i1.468

Suyanto, S. (2016). Character discourse between students and school teachers in Yogyakarta Special Province in Indonesia. Jurnal Pendidikan Karakter, 6(2). https://doi.org/10.21831/jpk.v6i2.12051

Syam, H., \& Yusuf, A. M. (2019). Group guidance model with cinema counseling technique as a prevention of gay influence for students. Padang International Conference on Educational Management And Administration (PICEMA 2018). https://doi.org/10.2991/icoie-18.2019.45How to use a DOI?

Tiwari, S. K. (2020). Identifying character education for research: discourse of relationship with culture, religion and other terms. Studies in Indian Place Names, 40(60), 917-933. https://scholar.google.com/

Undang-undang Nomor 20 Tahun 2003. (2016). Undang-Undang Nomor 20 Tahun 2003 tentang Sistem Pendidikan Nasional. Depertemen Pendidikan dan Kebudayaan RI.

Utama, A. (2017). Pengaruh layanan bimbingan kelompok dengan teknik sosiodrama terhadap sikap saling menghargai siswa dalam bergaul dengan teman sebaya pada siswa kelas $\mathrm{X}$ di sekolah menengah atas negeri 1 Palembang. Jurnal Konseling Komprehensif: Kajian Teori dan Praktik Bimbingan dan Konseling, 4(1), 58-68. https://scholar.google.com/

Yakub, Y., \& Abdurrahman, A. (2019). Modus pelayanan bimbingan dan konseling islam sebagai upaya pencegahan bahaya narkoba. ENLIGHTEN: Jurnal Bimbingan Konseling Islam, 2(1), 40-51. https://doi.org/10.32505/enlighten.v2i1.1217

Yasipin, Y., Rianti, S. A., \& Hidaya, N. (2020). Peran agama dalam membentuk kesehatan mental remaja. Manthiq, 5(1), 25-31. http://dx.doi.org/10.29300/mtq.v5i1.3240

Yetti, V. (2017). Pengaruh layanan bimbingan kelompok dalam mengembangkan sikap sosial siswa kelas VII di SMPN 1 Sungayang. repo.iainbatusangkar.ac.id. https://scholar.google.com/

Yunus, N. A. A. M., \& Ismail, R. (2017). Penghayatan agama, sikap dan tingkahlaku agresif sewaktu memandu (spirituality, attitude and aggressive driving). e-Bangi, 14(5). http://ejournals.ukm.my/ebangi/article/view/22589

Yusoff, S. H. M. (2019). Kaunseling, dakwah dan penerapan aspek akidah [Counselling, Da'wah and Applications of Action Aspects]. AL-QIYAM International Social Science and Humanities Journal, 2(4), 20-27. 